УДК 347.961

\title{
ИНФОРМАЦИОННЫЕ ТЕХНОЛОГИИ (ЭЛЕКТРОННЫЙ НОТАРИАТ): СРАВНИТЕЛЬНАЯ ХАРАКТЕРИСТИКА РОССИЙСКОГО И ЗАРУБЕЖНОГО ПРАВОВОГО РЕГУЛИРОВАНИЯ
}

\section{Галкина Анастасия Валериевна} студент

\section{Скачкова Ольга Сергеевна}

к.ю.н., доцент

ФГБОУ ВО «Самарский государственный экономический университет»

Аннотация: В статье рассмотрены актуальные вопросы создания электронного нотариата в Российской Федерации и зарубежных странах; выделены основные правовые новации, регулирующие совершение удаленных нотариальных действий; обозначены дальнейшие перспективы развития электронного нотариата.

Ключевые слова: электронные нотариат, удаленные нотариальные действия, усиленная электронная цифровая подпись.

\section{INFORMATION TECHNOLOGIES (ELECTRONIC NOTARY OFFICE): COMPARATIVE CHARACTERISTICS OF RUSSIAN AND FOREIGN LEGAL REGULATION}

\section{Galkina Anastasiya Valerievna Skachkova Olga Sergeevna}

\begin{abstract}
The article discusses the current issues of creating an electronic notary in the Russian Federation and foreign countries; highlights the main legal innovations that regulate the performance of remote notarial actions; identifies further prospects for the development of an electronic notary.

Key words: electronic notary, remote notary actions, enhanced electronic digital signature.
\end{abstract}

Стремительное развитие гражданского оборота и проникновение в его среду цифровизации привело к возникновению электронного 


\section{НАУКА, ОБЩЕСТВО, КУЛЬТУРА: ПРОБЛЕМЫ И ПЕРСПЕКТИВЫ ВЗАИМОДЕЙСТВИЯ В СОВРЕМЕННОМ МИРЕ}

документирования в системе нотариата, внедрения электронных нотариальных действий и сделок.

В соответствии с Федеральным законом «О внесении изменений в отдельные законодательные акты Российской Федерации» от 21.12.2013 № 379Ф3 в Российской Федерации была создана Единая информационная система нотариата (далее по тексту - ЕИСН), обеспечивающая хранение юридически значимых сведений, используемых в работе нотариусов, создание нотариусами нотариально оформленных документов в электронном формате, принятие и использование электронных документов для совершения различных нотариальных действий [1].

Создание ЕИСН было нацелено на создание сервиса с применением передовых информационных технологий, обеспечивающего хранение, обмен информацией между участниками внутри системы.

Использование ЕИСН позволяет нотариусам осуществлять взаимодействие с Росреестром, МВД, ФНС, органами ЗАГС, банками по получению и проверке достоверности информации.

С помощью ЕИСН обеспечивается межведомственное электронное взаимодействие и оказание услуг юридическим и физическим лицам через самостоятельное получение нотариусом необходимой информации для совершения нотариального действия [2, с. 341].

С 2018 года все нотариальные действия подлежат обязательной электронной регистрации.

Благодаря цифровизации нотариата в 2019 году увеличилось количество нотариальных услуг по удостоверению равнозначности документа на бумажном носителе его электронному аналогу. Число заявок на совершение таких сделок составило в 2019 г. 2,5 млн., что в 2 раза меньше, чем в 2018 году $[3]$.

С 1 февраля 2020 года введено обязательное требование о регистрации нотариусами всех сделок по отчуждению недвижимости в электронном виде в Росреестре с использованием сервиса ЕИС 2.0. [4, с. 283-284].

Следующим шагом в развитии электронного нотариата стало принятие Федерального закона «О внесении изменений в Основы законодательства о нотариате и отдельные законодательные акты Российской Федерации» от 27.12.2019 № 480-Ф3, предоставившего возможность гражданам совершать удаленные нотариальные действия и дистанционные сделки с участием двух и более нотариусов [5]. Подобный подход был взят из функционирования 


\section{НАУКА, ОБЩЕСТВО, КУЛЬТУРА: ПРОБЛЕМЫ И ПЕРСПЕКТИВЫ ВЗАИМОДЕЙСТВИЯ В СОВРЕМЕННОМ МИРЕ}

нотариата во Франции, где сделки с участием двух и более нотариусов используются уже несколько лет.

Граждане РФ самостоятельно выбирают нотариуса, к которому они будут обращаться. Нотариус проводит экспертизу будущей сделки, удостоверяет ее достоверность сделки и осознанной воли ее сторон, создает проект сделки в электронном формате с помощью ЕИСН с учетом условий, которые были согласованы с участниками сделки.

Участники сделки в присутствии нотариусов подписывают сделку с помощью электронной цифровой подписи, а нотариусы ставят усиленную электронную подпись на экземплярах сделки.

При удаленном электронном заключении сделки на участников сделки, в том числе и на нотариусов, налагается имущественная ответственность за действия и ошибки. При проведении и регистрации сделок с недвижимостью одним из обязательных условий является нахождения нотариуса в том субъекте Российской Федерации, где находится объект, подлежащий отчуждению [6].

Большая часть правовых норм, рассматриваемого федерального закона, вступила в юридическую силу с 29 декабря 2020 года.

В частности новшеством нотариального законодательства стало введение удаленных нотариальных действий, среди которых взыскание долгов с помощью исполнительной надписи нотариуса при установленной бесспорной задолженности.

Без личного визита в нотариальную контору граждане удаленно смогут получить услуги нотариуса по удостоверению перевода текста, переводу денежных средств иному лицу, осуществить внесение денежных средств на депозит нотариуса, передать нотариусу на хранение электронные документы, получить обеспеченные доказательства в виде осмотра информации в сети Интернет, затребовать выписку из Реестра уведомлений о залоге движимого имущества и др.

Правовым новшеством выступает и нанесение на документы нотариусов QR-кодов, защищающих их от подделок. QR-код выступает средством цифровой защиты документа и содержит всю необходимую информацию о заявителе, дате совершения нотариального действия, сведениях о нотариусе, нотариальном округе.

Действующее законодательство в сфере электронного нотариата в РФ предоставляет гражданам широкие возможности в использовании информационных технологий и сервисов для совершения различных действий. 


\section{НАУКА, ОБЩЕСТВО, КУЛЬТУРА: ПРОБЛЕМЫ И ПЕРСПЕКТИВЫ ВЗАИМОДЕЙСТВИЯ В СОВРЕМЕННОМ МИРЕ}

Использование сведений сайта Федеральной нотариальной палаты дает возможность гражданам получить информацию о подлинности и действительности доверенностей, о наличии или отсутствии залога, осуществить поиск сведений о наследниках и открытом наследственном деле и др.

Несмотря на то, что граждане благодаря функционированию МФЦ могут самостоятельно получить необходимые выписки или сведения, например, выписку из ЕГРН, сохраняется актуальность обращения к нотариусу за данной услугой. Получение нотариусом выписки из ЕГРН защищает получателя бумажной выписки от ее фальсификации и использования информации в незаконных целях.

Вместе с тем внедрение продвинутых цифровых технологий в систему нотариата обозначило и новое проблемное поле, которое нуждается в дальнейшем правовом регулировании.

К проблемным аспектам, нуждающимся в дальнейшем регулировании, относится использование в сделках и операциях электронной цифровой подписи. Существует риск того, что электронная цифровая подпись будет храниться ее владельцем в ненадлежащих условиях и может быть доступна другим лицам, либо подпись может быть получена не тем лицом, на которого она оформлена. Данные обстоятельства могут привести мошенническим действиям в сделках, где в качестве участника выступает нотариус и несет ответственность за достоверность сведений и совершаемых действий [7].

В подобных обстоятельствах гражданин должен обратиться в Росреестр с заявлением о том, что он разрешает использовать документы со своей цифровой подписью. Данное действие придаёт определенную легитимность цифровой сделке с применением электронной цифровой подписи, но не решает проблему возможных мошеннических действий.

Дальнейшее развитие правового регулирования электронного нотариата в Российской Федерации связано с созданием реестра недееспособных лиц, использованием и проверкой биометрических данных, защите и использованию усиленной электронной подписи нотариусов.

Законодательство об электронном нотариате в зарубежных странах имеет похожие тенденции. Так, во многих европейских странах идет процесс создания специальных цифровых ресурсов для размещения нотариальной информации, совершения удаленных сделок и действий посредством электронной цифровой подписи. 


\section{НАУКА, ОБЩЕСТВО, КУЛЬТУРА: ПРОБЛЕМЫ И ПЕРСПЕКТИВЫ ВЗАИМОДЕЙСТВИЯ В СОВРЕМЕННОМ МИРЕ}

В странах, входящих в Европейский Союз, развитие информационных технологий, электронных систем, внедрение новых сервисов в структуре нотариата координируется Советом Нотариатов Европейского Союза.

Нотариусы стран-участниц Европейского союза в своей деятельности используют такие сервисы, как:

- Европейская сеть реестра завещаний (ENRWA) для регистрации и ведения реестра завещаний, брачных контрактов, получения свидетельств на наследство;

- платформа для обмена информацией в сфере недвижимости (EUFides);

- Европейская нотариальная сеть обеспечивает трансграничное сотрудничество, доступ к различной информации по трансграничным сделкам $[8$, c. 187$]$.

В качестве основных направлений правового регулирования электронного нотариата в странах Европейского Союза является дальнейшее совершенствование законодательства в отношении применения электронной системы удостоверенных документов, использования электронной цифровой подписи, создание новых электронных платформ и реестров для поддержки нотариальных действий и хранения информации, развитие национальных систем электронного нотариата.

Есть в функционировании электронного нотариата в зарубежных странах и свои особенности.

Так, например, для Австрии характерно функционирование нотариата как института предварительного правосудия, где отдается приоритет личному контакту нотариуса и клиента. Вместе с тем законодательством закреплено совершение нотариальных сделок дистанционно [9].

Из опыта развития электронного нотариата Германии можно отметить процесс подписания договоров удаленно. В соответствии с законодательством ФРГ нотариус предоставляет клиенту проект договора. Клиенту дается две недели на изучение договора, проведение необходимых консультаций с юристами, другими специалистами. Подобный подход защищает интересы клиента при дистанционном заключении договора, делает процесс более прозрачным.

Многие операции, совершаемые немецкими нотариусами с в формате электронного нотариата во многом аналогичны российским. Так, например, 


\section{НАУКА, ОБЩЕСТВО, КУЛЬТУРА: ПРОБЛЕМЫ И ПЕРСПЕКТИВЫ ВЗАИМОДЕЙСТВИЯ В СОВРЕМЕННОМ МИРЕ}

нотариусы Германии запрашивают необходимые выписки для своих клиентов из поземельной книги, являющейся аналогом ЕГРН в РФ. Обеспечение достоверности сведений поземельной книги осуществляется внесением сведений в нее исключительно нотариусами. Нотариусы Германии имеют возможность электронного внесения сведений в реестр недвижимости поземельной книги.

В системе германского электронного нотариата ведется работа по созданию и правовому закреплению функционирования центрального электронного архива и полном переводе документооборота нотариусов в электронный формат после 2020 года.

Франция рассматривается в качестве страны с передовым электронным нотариатом, опыт которой послужил в качестве отправной точки для цифровизации нотариата в Российской Федерации [10].

На Международном союзе нотариата, который состоялся в апреле 2020 г. в Джакарте Лионель Гальез, нотариус из Франции, являющийся координатором Европы в Международном союзе нотариата, отметил о необходимости дальнейшего правового регулирования такого вопроса, как расширение сферы профессионального участия нотариусов, в том числе и в дистанционном формате.

Так, Л.Гальез предложил включить нотариусов в качестве участников корпоративных процедур и финансовых отношений и с привлечением их в работу Всемирного банка. Данная позиция позволяет судить о развитии такого направления электронного нотариата, как международный электронный нотариат.

В Китайской системе цифрового нотариата наблюдается тенденция по созданию сервисов для нотариального удостоверения авторских прав с целью последующей их защиты. Первые шаги по созданию платформы по защите интеллектуальных и авторских прав показали, что она позволяет выявлять и отслеживать нарушения авторских прав с любой сфере [11].

В зарубежных странах ведется работа по созданию правовых основ использования блокчейн-платформы нотариальных услуг, с помощью которой удостоверение подлинности документов будет основано на применении вычислительных алгоритмов без участия человека.

Таким образом, можно отметить, что развитие электронного нотариата в Российской Федерации и зарубежных странах связано с созданием новых правовых механизмов и совершенствованием уже имеющихся, которые 
определяют статус нотариуса в условиях цифровой глобализации, перечень удаленных сделок, защиту цифровой подписи, порядок удостоверения документов и электронных сделок, взаимодействие с различными органами, электронную архивизацию документов, использование биометрических данных.

\section{Список литературы}

1. Федеральный закон «О внесении изменений в отдельные законодательные акты Российской Федерации» от 21.12.2013№ 379-Ф3 (последняя редакция) //Консультант Плюс [Электронный ресурс]. Режим доступа: http://www.consultant.ru/document/cons_doc_LAW_156007/ (дата обращения: 12.03.2021).

2. Федеральный закон «О внесении изменений в Основы законодательства о нотариате и отдельные законодательные акты Российской Федерации» от 27.12. 2019 № 480-Ф3//Консультант Плюс [Электронный pecypc]. Режим доступа: http://www.consultant.ru/document/cons_doc_LAW_ 341788/ (дата обращения: 14.03.2021).

3. Булыгин А.Д. Совершенствование электронного документооборота с Единой информационной системой нотариата// Молодой ученый. - 2020. - № 19 (309). - С. 283-284 [Электронный ресурс]. Режим доступа: https://moluch.ru/ archive/309/69910/ (дата обращения: 15.03.2021).

4. Козина Е. Закон о цифровом нотариате: удаленная работа нотариусов, бесконтактные сделки, цифровизация данных//Информационно-правовой портал ГАРАНТ.РУ [Электронный ресурс] Режим доступа: https://www.garant.ru/ia/opinion/author/kozina/1428623/ (дата обращения: 12.03.2021).

5. Куликов В. Исследование выявит риски использования информтехнологий в праве // Российская газета. 26.04.2020 [Электронный pecypc] Режим доступа: https://rg.ru/2020/04/26/issledovanie-vyiavit-riskiispolzovaniia-informtehnologij-v-prave.html (дата обращения: 14.03.2021).

6. Махова Ю.И. Использование электронных ресурсов в нотариальной деятельности в России и странах ЕС// Международный журнал гуманитарных и естественных наук. - 2017. - № 10. - С. 184-188.

7. Новый этап в развитии электронного нотариата одобрен законодателем: детали // Федеральная нотариальная палата [Электронный pecypc]. Режим доступа: https://notariat.ru/ru-ru/news/novyj-etap-v-razvitii- 
elektronnogo-notariata-odobren-zakonodatelem-detali (дата обращения: 14.03.2021).

8. Нотариат в условиях глобальной пандемии: российский и зарубежный опыт. Новые «цифровые» вызовы//Сайт «Сфера» [Электронный ресурс]. Режим доступа: https://lfacademy.ru/sphere/post/notariat-v-usloviyah-globalnoi-pandemiirossiiskii-i-zarubezhnyi-opyt-novye-cifrovye-vyzovy (дата обращения: 14.03.2021).

9. Радченко И. Нотариус: электронные технологии все ускоряют и делают нас уязвимыми//РИА Новости. Недвижимость [Электронный ресурс]. Режим доступа: https://realty.ria.ru/20191223/1562718419.html (дата обращения: 14.03.2021).

10. Тарасова Е.А. Современный нотариат=электронный нотариат? (цифровизация нотариальной деятельности)//Пермский юридический альманах. - 2019.- № 1. - С. 337-344.

11. Цифровизация нотариата в настоящем и перспективы будущего// Сайт «Долг. РФ» [Электронный ресурс]. Режим доступа: https://yandex.ru/ turbo/xn-c1abvl.xn-p1ai/s/news/pravo/tsifrovizatsiya_notariata_v_2018_2020_gg_ i_perspektivy_budushchego/ (дата обращения: 14.03.2021). 